\title{
EKSISTENSI PONDOK PESANTREN SIDOGIRI \\ PASURUAN DALAM MEMPERTAHANKAN \\ NILAI-NILAI SALAF DI ERA GLOBALISASI
}

\author{
Oleh: \\ M. Ma'ruf, M.Pd.I \\ Dosen STIT PGRI Pasuruan \\ ahmadm4ruf@gmail.com
}

\begin{abstract}
Abstrak
Artikel ini mendeskripsikan dan mengeksplorasi sistem pendidikan pesantren sidogiri sehingga masih eksis dalam mempertahankan nilainilai salaf di era globalisasi sekarang, serta upaya mempertahankannya. Data dalam penelitian ini didapatkan dari observasi, interview dan dokumentasi. Hasil penelitian menunjukkan bahwa Sistem pendidikan Pondok Pesantren Sidogiri Pasuruan ada 3 tingkat yaitu; Madrasah Ibtidaiyah, Madrasah Tsanawiyah dan Madrasah Aliyah. Sedangkan untuk santri baru wajib mengikuti Madrasah Idadiyah. Untuk mempertahan nilai-nilai salafnya pondok sidogiri masih menggunakan kitab kuning atau kitab klasik dalam proses ta'lim. Dalam metode pengajarannya masih menerapkan metode-metode salaf seperti sorogan dan wetonan. Selain itu kegiatan-kegiatan religius tetap dipertahankan serta penanaman tawadhu'antara santri dan guru baik dilingkungan pesantren maupun diluar. Adapun upaya pondok sidogiri dalam mempertahankan eksistensi dan nilai-nilai salafnya di era globalisasi saat ini dengan mengadakan studi banding antar pesantren, membuat metode baca kitab cepat yang dinamai dengan Al-Miftah lil Ulum sebagai persiapan bagi santri-santri usia dini, serta memberi jadwal khusus dan rutin kegiatan bahtsul masail untuk membahas persoalanpersoalan agama terkini dan kaderisasi An-Najah yang bertujuan untuk pendalaman akidah Ahlissunnah wal Jama'ah dan ilmu-ilmu kemasyarakatan.
\end{abstract}

Kata kunci: Pondok pesantren, Salaf,Globalisasi

\section{A. Pendahuluan}

Pondok Pesantren merupakan lembaga pendidikan sekaligus sebagai komunitas santri "ngaji" Ilmu Agama Islam. Pondok Pesantren sebagai lembaga pendidikan tertua di Indonesia, yang telah berdiri dan 
berkembang sejak ratusan tahun lalu, masih eksis dan dibutuhkan kehadirannya di tengah-tengah masyarakat muslim Indonesia sampai sekarang ini.

Tradisi Pondok Pesantren paling tidak memiliki lima elemen dasar, yakni pondok, masjid, santri, pengajaran kitab-kitab klasik (kitab kuning) dan Kyai. Pondok Pesantren tradisional (salaf) merupakan lembaga pendidikan islam dibawah kepemimpinan Kyai dan dibantu oleh seseorang yang ahli ilmu (ulama') atau para ustadz yang hidup bersamasama ditengah-tengah para santri ${ }^{1}$.

Untuk proses pembelajaranPondok Pesantrendilakukan melalui metode tradisional baik berupa pendidikan formal di sekolah atau madrasah dengan jenjang yang bertingkat atau pemberian pengajaran dengan sistem halaqah dalam bentuk wetonan dan sorogan. Penyampaian materi pengajian lazimnya dilakukan oleh kyai sesudah melakukan shalat fardlu. Sedang jadwal pengajian tidak diorganisir seperti di sekolah-sekolah yang menggunakan ukuran disiplin waktu, melainkan disesuaikan dengan waktu shalat fardlu. Ini dimaksudkan agar mereka dapat melakukan shalat secara berjamaah. ${ }^{2}$

Pada umumnya Pondok Pesantren di Indonesia masih tetap bertahan dengan sistem pendidikan lama, selanjutnya dikenal dengan Pondok Pesantrensalaf,yaitu Pondok Pesantren yang mempertahankan sistem pendidikan tradisionalnya.Pondok Pesantrensalaf atau Pondok Pesantren yang masih mempertahankan nilai-nilaitradisional, menyimpan potensi kesadaran multikultural. Wacana lokaldan rasionalitas lokal selama ini sudah diyakini menjadi custom atau tradisiPondok Pesantren. Demikian pula, konsep kemajuan bagi Pondok Pesantren ini juga bertitik tolak dari tradisi, sehingga tidak mengalami keterputusan sejarah ${ }^{3}$.

Pondok Pesantren Sidogiri merupakan salah satu Pondok Pesantren terbesar dan tertua yang tetap bertahan dengan nilai-nilai salafnya. Usia dari Pondok Pesantren ini kira-kira mencapai 278 tahun. Pondok Pesantren ini berdiri di area seluas kira-kira 4 hektar didiami

\footnotetext{
${ }^{1}$ Iskandar Engku, Sejarah Pendidikan Islam, (Bandung: Remaja Rosdakarya, 2014), hlm. 116.

${ }^{2}$ Sukamto, Kepemimpinan KIAI Dalam Pesantren, (Jakarta: Pustaka LP3ES, 1999), hlm. 43.

${ }^{3}$ Amin Rais, Cakrawala Islam, Antara Cita dan Fakta, (Bandung: Mizan, 1989), hlm. 162.
} 
kurang lebih 10.000 santri. ${ }^{4}$ Ciri- ciri dari Pondok Pesantren ini sebagai berikut :

1. Adanya penekanan pada penguasaan kitab klasik atau kitab kuning.

2. Masih diberlakukannya sistem pengajian sorogan dan wetonan dalam proses kegiatan belajar mengajar (KBM) santri.

3. Secara umum hubungan emosional kyai dan santri di Pondok Pesantren Sidogiri jauh lebih dekat dibanding Pondok Pesantren modern atau terpadu. Hal ini karena kyai menjadi figur sentral.

Selain karakteristik diatas, ada beberapa hal yang menarik dari Pondok Pesantren Sidogiri dan mendorong peneliti untuk melakukan penelitian di Pondok Pesantren tersebut, yaitu :

1. Pondok Pesantren Sidogiri memiliki keunikan dan karakteristik tersendiri dibandingkan Pondok Pesantren lain.

2. Merupakan Pondok Pesantren yang berjasa dengan kiprahnya dalam pembentukan sumber daya manusia (SDM) yang berilmu, beriman dan bertaqwa.

3. Merupakan Pondok Pesantren yang mampu menjawab tuntutan zaman, yaitu dengan kemampuannya dalam mempersiapkan kaderkader pemimpin umat.

Dari uraian di atas, penulis tertarik untuk mengambil lokasi penelitian di pondok pesantren sidogiri Pasuruan, sebab termasuk salah satu Pondok Pesantren terbesar dan tertua yang tetap bertahan dengan nilai-nilai salafnya dan telah mampu melahirkan banyak ulama' dan pemimpin-pemimpin umat yang tersebar di seluruh pelosok nusantara.

Dalam penelitian ini, peneliti memfokuskan riset pada sistem pendidikan pesantren sidogiri sehingga masih eksis dalam mempertahankan nilai-nilai salaf di era globalisasi sekarang, serta upaya mempertahankannya.

\section{A. Eksistensi Pondok Pesantren}

Keberadaan Pondok Pesantren di era modern merupakan fenomena tersendiri dalam dunia pendidikan sehingga menimbulkan hipotesis bahwa cara yang ditempuh Pondok Pesantren dalam mempertahankan eksistensi layak untuk diteliti. Hal ini disebabkan Pondok Pesantren merupakan lembaga pendidikan yang muncul jauh sebelum Indonesia terbentuk dan hingga sampai saat ini keberadaannya layak untuk diperhitungkan di era moderen. Jika dilihat dari sudut pandang historis

\footnotetext{
${ }^{4}$ Muhammad Sulton Fatoni, Kapital Sosial Pesantren, (Jakarta :Universitas Indonesia, 2015), hlm. 49.
} 
maka Pondok Pesantren adalah pewaris sah khazanah intelektual Indonesia terutama dalam khazanah keislaman.

\section{Pengertian Pondok Pesantren}

Pesantren merupakan "Bapak" dari pendidikan Islami di Indonesia, didirikan karena adanya tuntutan dan kebutuhan zaman. $\mathrm{Hal}$ ini bisa dilihat dari perjalanan sejarah, dimana pesantren dilahirkan atas kesadaran kewajiban dakwah Islamiah, yakni menyebarkan dan mengembangkan ajaran Islam, sekaligus mencetak kader-kader ulama' atau da'i. ${ }^{5}$

Pesantren sendiri menurut pengertian dasarnya adalah "tempat belajar para santri". Sedangkan pondok berarti rumah atau tempat tinggal sederhana yang terbuat dari bambu. Disamping itu kata "pondok" mungkin juga berasal dari bahasa Arab "Funduq" yang berarti "hotel atau asrama". 6

Pada awalnya Pondok Pesantren merupakan lembaga pendidikan dan pengajaran agama islam yang pada umumnya diberikan dengan cara non-klasikal (sistem pesantren), dimana seorang kyai mengajar santri-santri (siswa) berdasarkan kitab-kitab yang ditulis dalam bahasa Arab oleh ulama'-ulama' besar dari abad pertengahan (abad ke-12 s/d abad ke-16). Para santri biasanya tinggal dalam pondok atau asrama dalam pesantren tersebut. Namun demikian pada awalnya pesantren tidak memiliki pondok atau asrama, sehingga para santri yang belajar harus tinggal menyebar di desa-desa yang ada di sekitar pesantren tersebut. Para santri yang demikian itu disebut santri kalong, yang mengikuti pelajaran di pesantren secara wetonan, dimana mereka datang berduyun-duyun ke pesantren pada waktu tertentu yang ditentukan untuk mengikuti pelajaran. $^{7}$

Pondok dewasa ini telah berkembang dan merupakan lembaga gabungan antara sistem pondok dan pesantren, yang memberikan pendidikan dan pengajaran agama islam dengan sistem non-klasikal. Sedangkan santrinya dapat bermukim di pondok yang disediakan atau merupakan santri kalong (santri yang tidak bermukim di pondok). ${ }^{8}$

\footnotetext{
${ }^{5}$ Iskandar Engku, Sejarah Pendidikan Islam, hlm.115.

${ }^{6}$ Zamakhsyari Dhofier, Tradisi Pesantren, (Jakarta: LP3ES, 1983), hlm.18.

${ }^{7}$ Imron Arifin, Kepemimpinan Kyai, (Malang: Kalimasahada Press, 1993), hlm. 3.

${ }^{8}$ Imron Arifin, Kepemimpinan Kyai, hlm. 3.
} 
Pengambilan nama santri dari kata shastri yang berasal dari India (sansekerta) cukup masuk akal, mengingat bahwa penyebar islam pertama di Indonesia sebagian berasal dari Gujarat, India, dimana tokoh pertama yang merintis berdirinya pesantren di Jawa adalah Syekh Maulana Malik Ibrahim, seorang ulama' yang berasal dari Gujarat, India. ${ }^{9}$

\section{Elemen-Elemen Pondok Pesantren}

Tidak berbeda dengan Ali yang melihat Pondok Pesantren berisi lima komponen fisik. Dhofier juga menganggap bahwa untuk dapat memahamim keaslian suatu Pondok Pesantren, setidaktidaknya memang terdapat lima elemen minimal yang harus ada, ${ }^{10}$ yaitu :

a. Pondok

Sebuah pondok pada dasarnya merupakan sebuah asrama pendidikan islam tradisional dimana para santri tinggal di bawah bimbingan seorang kyai. ${ }^{11}$ Kata pondok yang berarti kamar, gubuk, rumah kecil yang dalam bahasa Indonesia menekankan pada kesederhanaan bangunan.

b. Masjid

Masjid merupakan unsur pokok kedua dari Pondok Pesantren, disamping berfungsi sebagai tempat melakukan shalat berjamaah setiap waktu, masjid juga berfungsi sebagai tempat belajar mengajar. ${ }^{12}$

c. Pengajaran kitab-kitab islam klasik

Unsur yang membedakan Pondok Pesantren dengan lembaga pendidikan lainnya adalah bahwa pada Pondok Pesantren diajarkan kitab-kitab klasik yang dikarang para ulama' terdahulu, mengenai berbagai macam ilmu pengetahuan agama islam dan bahasa Arab. ${ }^{13}$ Sejak tumbuhnya Pondok Pesantren, pengajaran kitab-kitab islam klasik diberikan sebagai upaya untuk meneruskan tujuan

\footnotetext{
${ }^{9}$ Imron Arifin, Kepemimpinan Kyai, hlm. 4.

${ }^{10}$ Zamakhsyari Dhofier, Tradisi Pesantren, hlm. 44.

${ }^{11}$ Zamakhsyari Dhofier, Tradisi Pesantren, hlm. 44.

${ }^{12}$ Iskandar Engku, Sejarah Pendidikan Islam, hlm. 118.

${ }^{13}$ Iskandar Engku, Sejarah Pendidikan Islam, hlm. 120.
} 
utama Pondok Pesantren mendidik calon-calon ulama', yang setia terhadap faham islam tradisional. ${ }^{14}$

d. Santri

Santri merupakan sebutan bagi para siswa yang belajar mendalami agama di Pondok Pesantren.Santri sendiri terbagi menjadi dua kelompok santri mukim(santri yang menetap di pondok) dan santri kalong (santri yang tidak menetap di pondok). ${ }^{15}$

e. Kyai

Kata-kata kyai bukan berasal dari bahasa Arab melainkan dari bahasa Jawa. Kata-kata kyai mempunyai makna yang agung, keramat dan dituahkan. Kyai merupakan tokoh sentral dalam Pondok Pesantren yang memberikan pengajaran. Karena itu kyai adalah salah satu unsur yang paling dominan dalam kehidupan suatu Pondok Pesantren. ${ }^{16}$

Kemasyhuran, perkembangan dan kelangsungan kehidupan suatu Pondok Pesantren bergantung pada keahlian dan kedalaman ilmu. Kharismatik dan wibawa, serta ketrampilan kyai yang bersangkutan dalam mengelola Pondok Pesantrennya. Dalam konteks ini, pribadi kyai sangat menentukan, sebab beliau adalah tokoh sentral dalam Pondok Pesantren.

\section{Tipe Pondok Pesantren}

Pondok Pesantren sebagai Lembaga Pendidikan Islam mengalami perkembangan bentuk sesuai dengan perubahan zaman terutama sekali adanya dampaknya kemajuan ilmu pengetahuan dan teknologi.

Secara vaktual tipe Pondok Pesantren terbagi menjadi 2, yaitu :

a. Pondok Pesantren salaf (tradisional)

Pondok Pesantren ini masih tetap mempertahankan bentuk aslinya dengan semata-mata mengajarkan kitab yang ditulis oleh ulama' pada abad ke 15 dengan menggunakan

\footnotetext{
${ }^{14}$ Iskandar Engku, Sejarah Pendidikan Islam, hlm. 120.

${ }^{15}$ Iskandar Engku, Sejarah Pendidikan Islam, hlm. 119.

${ }^{16}$ Iskandar Engku, Sejarah Pendidikan Islam, hlm. 118.
} 
bahasa Arab. Pola pengajarannya dengan menggunakan sistem halaqoh yang dilaksanakan di masjid atau surau.

b. Pondok Pesantren khalaf(modern)

Merupakan Pondok Pesantren yang berusaha mengintegrasikan secara penuh sistem klasikal dan sekolah kedalam Pondok Pesantren. Pengajian kitab klasik tidak begitu menonjol, bahkan ada yang cuman sebagai pelengkap, tetapi berubah menjadi mata pelajaran atau bidang studi. Begitu juga sistem yang diterapkan, seperti cara sorogan dan wetonan mulai berubah menjadi individual dalam hal belajar.

Variasi pondok pesantren tersebut perlu diadakan pembedaan secara kategorial. Kategori Pondok Pesantren modern dapat di teropong dari berbagai perspektif; dari segi kurikulumnya, materi mata pelajaran telah dilengkapi dengan mata pelajaran umum, dan ditambah pula dengan memberikan aneka macam pendidikan lainnya, seperti ketrampilan, kepramukaan, olahraga, kesenian dan pendidikan berorganisasi dan sebagian telah melaksanakan program pengembangan masyarakat.

\section{Peranan Pondok Pesantren}

Dalam kehidupan sosial keagamaan masyarakat Indonesia dan termasuk kehidupan politik, Pondok Pesantren memiliki peranan yang sangat penting dalam mengembangkan kehidupan di wilayah Indonesia. Bentuk peranan-peranan itu antara lain :

a. Peran instrumental

Upaya pendidikan secara nasional tak pelak lagi memerlukan sarana-sarana sebagai media untuk mengejawantahkan tujuan-tujuannya. Sarana-sarana itu selain dibentuk secara formal juga nonformal murni swadaya dari masyarakat. Dalam tataran inilah peranan Pondok Pesantren sebagai alat pendidikan nasional tampak sangat partisipatif. Peranan instrumental Pondok Pesantren demikian itu dalam kenyataannya memang cukup kuat meskipun perkembangannya sampai dewasa ini masih sangat dibutuhkan lebih serius. ${ }^{17}$

b. Peranan keagamaan

${ }^{17}$ Iskandar Engku, Sejarah Pendidikan Islam, hlm. 176. 
Dalam pelaksanaannya, Pondok Pesantren melaksanakan proses pembinaan pengetahuan, sikap dan kecakapan yang menyangkut segi keagamaan. Tujuan intinya adalah mengusahakan terbentuknya manusia berbudi luhur dengan pengamalan keagamaan yang konsisten. Pendidikan nasional sendiri bertujuan antara lain menciptakan manusia bertaqwa. Untuk kepentingan ini, pendidikan agama dikembangkan secara terpadu baik melalui sekolah umum maupun madrasah. ${ }^{18}$

\section{B. Sistem Pendidikan dan Pengajaran Pondok Pesantren}

1. Sistem Pendidikan di Pondok Pesantren

Pada dasarnya Pondok Pesantren adalah Lembaga Pendidikan Islam, dimana pengetahuan-pengetahuan yang yang berhubungan dengan agama Islam diharapkan dapat diperoleh di Pondok Pesantren. ${ }^{19}$ Apa pun usaha yang dilakukan untuk meningkatkan Pondok Pesantren di masa kini dan yang akan datang harus tetap pada prinsip ini. Artinya, Pondok Pesantren tetap sebagai Lembaga Pendidikan Islam dengan ciri-ciri khas, meskipun ia banyak terlibat dalam berbagai masalah kemasyarakatan seperti perekonomian, kesehatan, lingkungan dan pembangunan.

Sekalipun sampai saat ini tujuan di Pondok Pesantren belum dirumuskan secara rinci dan dijabarkan dalam suatu sistem pendidikan yang lengkap dan konsisten tapi secara umum tujuan itu tertuang dalam kitab Ta'limul Muta'allim, dimana tujuan seseorang menuntut ilmu dan mengembangkan ilmu adalah semata-mata karena kewajiban Islam yang harus dilakukan secara ikhlas. Tujuan ini pada gilirannya akan menjadi faktor motivasi bagi para santri untuk belajar melatih diri menjadi seorang yang ikhlas di dalam segala amal perbuatannya. Karena seseorang yang belajar di Pondok Pesantren berdasar asas keikhlasan, maka apabila ia telah lulus dari Pondok Pesantren tidak boleh memiliki pamrih apa pun. Sehingga terdapat pernyataan dari kalangan Pondok Pesantren bahwa tujuan pendidikan di Pondok Pesantren adalah membentuk manusia yang

\footnotetext{
${ }^{18}$ Iskandar Engku, Sejarah Pendidikan Islam, hlm. 177.

${ }^{19}$ Imron Arifin, Kepemimpinan Kyai, hlm. 35.
} 
bertaqwa, mampu hidup dengan kekuatan sendiri, tidak merupakan keharusan untuk menjadi pegawai negeri. ${ }^{20}$

Dengan demikian secara umum tujuan pendidikan di Pondok Pesantren adalah mendidik manusia yang mandiri dan berakhlak baik serta bertaqwa. Dari dimensi pendidikan membina budi pakerti anak didik dan dari dimensi pengajaran membina dan mengembangkan intelektual anak didik.

\section{Sistem Pengajaran di Pondok Pesantren}

Sistem Pondok Pesantren sebagai Lembaga Pendidikan Islam secara selektif bertujuan menjadikan para santrinya sebagai manusia yang mandiri yang diharapkan dapat menjadi pemimpin umat dalam menuju keridlaan Tuhan. ${ }^{21}$

Oleh karena itu Pondok Pesantren bertugas untuk mencetak manusia yang benar-benar ahli dalam bidang agama dan ilmu pengetahuan kemasyarakatan serta berakhlak mulia. Untuk mencapai tujuan tersebut maka Pondok Pesantren mengajarkan ilmu tauhid, ilmu fiqih, ilmu tafsir, ilmu hadits, ilmu nahwu, ilmu sharaf, ilmu ma'ani, ilmu badi' dan bayan, ilmu ushul fiqih, ilmu musthalah hadits dan ilmu manthiq. ${ }^{22}$

Pengajaran untuk ilmu-ilmu tersebut sering distandarisasikan dengan pengajaran kitab-kitab wajib (Kitabul Muqarrarah) sebagai buku teks yang dikenal dengan sebutan kitab kuning. Beragam kitab digunakan di Pondok Pesantren mulai yang sederhana seperti Safinatun Najah, Al Jurumiyah, Taqrib, Alfiyah, Tafsir Jalalain, Fathul Wahab, Mahalli, Minhajul Qowim sampai pengajaran takhassus dengan menggunakan kitab seperti: tafsir Ibnu Katsir, Al Baidlowi, Al Maraghi dan sebagainya. ${ }^{23}$

Ada beberapa metode yang dipergunakan untuk mendalami kitab-kitab standar (muqarrarah) di Pondok Pesantren, yaitu metode wetonan, metode sorogan/bandongan metode muhawarah, metode mudzakarah dan metode majlis ta'lim. Uraian metode-metode tersebut adalah sebagai berikut:

a. Metode Wetonan

Pelaksanaan metode pengajaran ini adalah sebagai berikut: Kyai membaca suatu kitab dalam waktu tertentu dan

\footnotetext{
${ }^{20}$ Imron Arifin, Kepemimpinan Kyai, hlm. 35

${ }^{21}$ Imron Arifin, Kepemimpinan Kyai, hlm. 37

${ }^{22}$ Imron Arifin, Kepemimpinan Kyai, hlm. 37.

${ }^{23}$ Imron Arifin, Kepemimpinan Kyai, hlm. 37
} 
santri membawa kitab yang sama, kemudian santri mendengarkan dan menyimak tentang bacaan kyai tersebut. Metode pengajaran yang demikian adalah metode bebas, sebab absensi santri tidak ada. Santri boleh datang, boleh tidak dan tidak ada pula sistem kenaikan kelas. Santri yang cepat menamatkan kitab yang lain. Metode ini seolah-olah mendidik anak supaya kreatif dan dinamis. ${ }^{24}$

Dalam metode wetonan ini dilakukan dengan cara seorang kyai duduk diingkari santri-santrinya. Kelompok santri itu kemudian mengikuti kyai yang membaca, menerjemahkan, menjelaskan, mengulas kitab dalam bahasa Arab itu. Kelompok santri yang mengikuti pelajaran seperti itu disebut halaqah yang berarti lingkaran belajar santri.

b. Metode Sorogan

Metode sorogan adalah aktivitas pengajaran secara individual, dimana setiap santri menghadap secara bergiliran kepada ustadz/kyai,untukmembaca, menjelaskan atau menghafal pelajaran yang diberikan sebelumnya. ${ }^{25}$

Metode tersebut merupakan kegiatan pembelajaran bagi para santri yang lebih menitik beratkan pada pengembangan kemampuan perorangan (individu), di bawah bimbingan seorang ustadz atau kyai. Bila santri dianggap menguasai maka ustadz atau kyai akan menambah dengan materi baru biasanya dengan membaca, mengartikan dan menjelaskan isi kandungan kitab tersebut.

Sementara itu ustadz atau kyai meneruskan apa yang telah dibaca atau mengartikan oleh santri-santri yang lain dengan prilakuan yang sama. Sitem sorogan terbukti sangat efektif sebagai taraf pertama oleh para santri yang bercita-cita sebagai pendakwah atau ustadz, dan ilustrasi seperti ini menumbuhkan atau gambaran yang jelas bagaimana metode ini dilaksanakan.

c. Metode Muhawarah

Muhawarah adalah suatu kegiatan berlatih bercakapcakap dengan bahasa Arab yang diwajibkan oleh Pondok

\footnotetext{
${ }^{24}$ Imron Arifin, Kepemimpinan Kyai, hlm. 38.

${ }^{25}$ Imam Bawani MA, Tradisionalisme dalam Pendidikan Islam, (Surabaya : al-ikhlas, 1993), hal. 97.
} 
Pesantren kepada para santri selama mereka tinggal di pondok. ${ }^{26}$ Di beberapa Pondok Pesantren, latihan muhawarah atau muhadasah tidak diwajibkan setiap hari, akan tetapi hanya satu kali atau dua kali dalam seminggu yang digabungkan dengan latihan muhadlarah atau khitabah, yang tujuannya melatih ketrampilan anak didik berpidato.

d. Metode Mudzakarah

Mudzakarah merupakan suatu pertemuan ilmiah yang secara spesifik membahas masalah diniyah seperti ibadah dan akidah serta masalah agama pada umumnya. ${ }^{27}$

Dalam mudzakarah tersebut dapat dibedakan atas dua tingkat kegiatan: pertama mudzakarah diselenggarakan oleh sesama santri untuk membahas suatu masalah dengan tujuan melatih para santri agar terlatih dalam memecahkan persoalan dengan mempergunakan kitab-kitab yang tersedia. Salah seorang santri mesti ditunjuk sebagai juru bicara untuk menyampaikan kesimpulan dari masalah yang didiskusikan. Kedua mudzakarah yang dipimpin oleh kyai, dimana hasil mudzakarah para santri diajukan untuk dibahas dan dinilai seperti dalam suatu seminar. Biasanya lebih banyak berisi suatu tanya jawab dan hampir seluruhnya diselenggarakan dalam bahasa Arab.

Saat mudzakarah inilah santri menguji ketrampilannya baik dalam bahasa Arab maupun ketrampilannnya mengutip sumber-sumber argumentasi dalam kitab-kitab klasik Islam. Mereka yang dinilai oleh kyai cukup matang untuk menggali sumber-sumber referensi, memiliki keluasan bahan-bahan bacaan dan mampu menemukan atau menyelesaikan problemproblem menurut analisis jurisprudensi madzhab Syafi'i, maka santri tersebut akan ditunjuk menjadi pengajar kitab-kitab yang dikuasainya.

e. Metode Majlis Ta'lim

Majlis $T a^{\prime} l i m$ adalah suatu media penyampaian ajaran Islam yang bersifat umum dan terbuka. Para jama'ah terdiri dari berbagai lapisan yang memiliki latar belakang pengetahuan bermacam-macam dan tidak dibatasi oleh tingkatan usia

${ }^{26}$ Imron Arifin, Kepemimpinan Kyai, hlm. 39.

${ }^{27}$ Imron Arifin, Kepemimpinan Kyai, hlm. 39. 
maupun perbedaan kelamin. Pengajian semacam ini hanya diadakan pada waktu -waktu tertentu saja. ${ }^{28}$

Ada yang seminggu sekali dan ada yang dua minggu sekali atau sebulan sekali. Kadang juga kyai mengadakan pengajian khusus untuk wanita. Materi pelajaran yang diberikan bersifat umum berisi nasehat-nasehat keagamaan yang bersifat amar ma'ruf nahi munkar.

\section{Pondok Pesantren di Era Globalisasi}

Seiring laju perkembangan masyarakat, Pondok Pesantren juga mengalami dinamika dan selalu berbenah diri agar tetap sesuai dengan tuntutan perubahan. Pondok Pesantren sedikit demi sedikit secara berangsur-angsur terus mengadakan pembaruan-pembaruan pada sistem pendidikannya. $^{29}$

Setidak-tidaknya ada tiga hal utama yang telah dilakukan Pondok Pesantren dalam meraih konstruksi sistem pendidikan. Pertama, pembaruan dari segi metode belajar mengajar dalam Pondok Pesantren. Pada mulanya Pondok Pesantren hanya menerapkan sistem menghafal, dan menempatkan kyai sebagai satu-satunya sumber dalam proses belajar mengajar. Tapi sekarang, sistem modern telah juga dipraktikkan dalam berbagai pesantren. Pembaruan dari segi muatan isi kurikulumnya. Pondok Pesantren tidak lagi mengajarkan sebatas pengetahuan keagamaan, melainkan telah juga diajarkan pendidikan sosial dan teknologi. ${ }^{30}$

Pembaruan dari segi mengoptimalkan Pondok Pesantren sebagai pusat pengembangan masyarakat (center of society development). Pengembangan yang dimaksud di sini adalah penyesuaiannya dengan dunia modern dengan tetap memelihara identitas keislaman. Yaitu, membekali para santri dengan berbagai disiplin keilmuan dan keterampilan dalam memasuki dunia modern dengan tetap berpegang pada tuntutan-tuntutan spiritual, syariat dan akhlak Islam.

Sampai sekarang, Lembaga Pendidikan Pesantren masih tetap diminati oleh sebagian umat Islam di Indonesia. Bahkan semakin popular

\footnotetext{
${ }^{28}$ Imron Arifin, Kepemimpinan Kyai, hlm. 39

${ }^{29} \mathrm{http} / / /$ waromuhammad.blogspot.co.id/2012/03/pesantren-dalam-era-modern.html, diakses pada tanggal 3 September 2016 pukul 23.56

${ }^{30} \mathrm{http}: / /$ waromuhammad.blogspot.co.id/2012/03/pesantren-dalam-era-modern.html, diakses pada tanggal 3 September 2016 pukul 23.56
} 
setelah memeberikan perhatian khusus dalam pengembangan dan pembinaannya.

Daya tarik Pondok Pesantren bagi sebagian umat Islam, tidak terlepas dari akibat yang ditimbulkan oleh perkembangan dunia modernyang sering membawa perkembangan negatif bagi perkembangan remaja. Dengan memasukkan anaknya ke Pondok Pesantren, para orang tua berharap agar anaknya mempunyai keseimbangan antara pengetahuan umum dan pengetahuan keagamaan yang tinggi, sehingga diharapkan akan terbentuk akhlakul karimah pada anak tersebut.

\section{Sistem Pendidikan Pondok Pesantren Sidogiri Pasuruan}

Sistem Pendidikan di Pondok Pesantren Sidogiri dibagi menjadi 3 tingkat. Madrasah Ibtidaiyah, Madrasanah Tsanawiyah dan Madrasah Aliyah. Selain itu untuk santri baru sebelum masuk ke Madrasah Ibtidaiyah wajib masuk ke Madrasahldadiyah yang materinya khusus mempelajari bagaimana cara membaca kitab. Untuk mata pelajaranya sendiri (fan) ada Tauhid, Fikih, Nahwu yang menjadi fan pokok ditingkat Madrasah Ibtidaiyah masa ada fan dasar seperti Falak, Imla', Tajwid, Sorof, I'lal, Tarikh, Tafsir dan Faroidl. . Dan metode pengajaran yang digunakan masih tradisional akan tetapi untuk tingkat Aliyah ada penjurusan khususnya jurusan Mu'amalah biasanya menggunakan media LCD karena berhubungan dengan grafik.

Madrasah Ibtida'iyah adalah Lembaga Pendidikan klasikal pertama yang ada di Pondok Pesantren Sidogiri. Adapun mata pelajaran agama dasar dan sedikit memasukkan pelajaran umum, seperti Bahasa Indonesia dan Matematika. Untuk kegiatan pendukung di Madrasah Ibtida'iyah ini yaitu pada sore hari (17.00 - 17.50 WIS) diadakan kegiatan musyawarah. Sejak tahun lalu kegiatan musyawarah diganti dengan pembinaan baca kitab cepat Al-Miftah lil-ulum dan langsung dipraktikkan pada kitab Fikih yang dipelajari dari kelas masing-masing. Hal ini sebagai upaya untuk mencapai target dari Madrasah Ibtida'iyah yaitu membaca dan memahami kitab pelajarannya sendiri. ${ }^{31}$

Dalam pembinaan metode al-Miftah ini, murid dikelompokkan dalam kelas berdasarkan sistem modul perjilid (total ada empat jilid).

Untuk Madrasah Tsanawiyah adalah Lembaga Pendidikan klasikal setelah tingkat Ibtida'iyah yang terdiri atas tiga kelas (I, II, dan III).

\footnotetext{
${ }^{31}$ Tim Penyusun Jurnal Tamassya, Berakhlak Bermartabat, (Pasuruan: Sekretariat Pondok Pesantren Sidogiri, 2016), hlm.83.
} 
Lulusan dari tingkat Tsanawiyah ini diwajibkan melaksanakan tugas mengajar selama satu tahun di Lembaga Pendidikan yang membutuhkan, dan ini merupakan persyaratan untuk memperoleh ijazah. Sejak tahun 1435-1436 H murid yang dapat melaksanakan tugas mengajar hanya yang berusia minimal 19 tahun, sedangkan yang tidak sampai batas usia tersebut langsung melanjutkan ke tingkat Madrasah Aliyah. $^{32}$

Oleh karena tugas mengajar merupakan persyaratan untuk memperoleh ijazah, maka bagi santri yang tidak menjalankan tugas mengajar, ijazah mereka diserahkan ketika setelah satu tahun (setelah kelas satu Aliyah). Di tingkat Tsanawiyah ini, sejak tahun 1429-1430 H diadakan kelas akselerasi (percepatan) atau bisa disebut PK (Program Khusus). Untuk kelas II, nilai baca kitab menjadi persyaratan kenaikan kelas. Untuk target dari Madrasah Tsanawiyah ini adalah murid mampu memahami kitab pelajaran plus beberapa kitab syarh. ${ }^{33}$

Madrasah Aliyah merupakan tingkat akhir dari semua jenjang pendidikan klasikal di Pondok Pesantren Sidogiri. Sejak tahun 1425-1426 H menerapkan sistem kejuruan di kelas II dan III dengan tiga jurusan; Tarbiyah (konsentrasi bidang pendidikan), Dakwah (konsentrasi bidang dakwah) dan Mu'amalah (konsentrasi bidang ekonomi syari'ah). Pada tahun 1433-1434 H Madrasah Aliyah ini menambah dua jurusan lagi, Tafsir dan Hadist yang sejak tahun $1435 \mathrm{H}$ digabung menjadi satu jurusan (Tafsir-Hadist). ${ }^{34}$

Dapat disimpulkan bahwa Pondok Pesantren Sidogiri mempunyai tiga tingkatan Pendidikan yaitu Madrasah Ibtida'iyah adalah Lembaga Pendidikan dasar, Madrasah Tsanawiyah adalah Lembaga Pendidikan setelah Madrasah Ibtida'iyah dan Madrasah Aliyah adalah pendidikan tingkat akhir yang ada di Pondok Pesantren Sidogiri Kabupaten Pasuruan.

\section{E. Eksistensi Pondok Pesantren Sidogiri dalam Mempertahankan Nilai- Nilai Salaf di Era Globalisasi}

Pondok Pesantren Sidogiri masih kental dengan nilai-nilai salaf, seperti tetap memakai kitab kuning yang digunakan sebagai sumber belajar. Selain itu dalam sagala hal hampir santri tidak lepas dari

\footnotetext{
${ }^{32}$ Tim Penyusun Jurnal Tamassya, Berakhlak Bermartabat, hlm.84.

${ }^{33}$ Tim Penyusun Jurnal Tamassya, Berakhlak Bermartabat, hlm.84.

${ }^{34}$ Tim Penyusun Jurnal Tamassya, Berakhlak Bermartabat, hlm.85.
} 
memakai sarung. Baik ketika madrasahmaupun kegiatan-kegiatan yang lain. ${ }^{35}$ Meskipun saat ini banyak Pondok Pesantren yang berbasis modern khususnya di daerah Pasuruan dan sekitarnya. Dengan demikian eksistensi Pondok Pesantren Sidogiri tidak kalah menarik minat orang tua untuk memondokkan di Pondok Pesantren Sidogiri ini.

Sementara itu, peneliti juga melihat disela-sela waktu luang banyak santri yang menghabiskan waktunya di Perpustakaan atau di halamanhalaman sambil mempelajari kitab kuning. ${ }^{36}$ Ada juga yang belajar di Masjid, Surau atau tempat-tempat lainnya ketika tidak ada jam Madrasah. Karena untuk Madrasah sendiri berbeda jam masuknya untuk Madrasah Ibtidaiyah pagi dan untuk siang setelah Shalat Dhuhur Madrasah Tsanawiyah dan Madrasah Aliyah.

Kegiatan sehari-hari para santri Pondok Pesantren Sidogiri sangat sederhana tetapi tidak mengurangi nilai kesalafan yang diajarkan oleh guru-guru mereka, seperti halnya sholat wajib berjama'ah, pembacaan maulid Nabi SAW serta kegiatan salaf yang lainya dengan tujuan untuk menumbuhkan sikap, akhlaq dan budi pekerti yang baik bagi para santri , hal ini terbukti dengan sikap tawadlu' para santri kepada guru mereka. ${ }^{37}$

Contoh kecil ketika muhaddastah atau berbicara dengan guru, santri tersebut tidak berani untuk memandang wajah gurunya serta tidak berani untuk mengangkat suaranya melebihi suara gurunya tersebut. Hal ini sudah menandakan bahwa nilai-nilai salaf itu tidak hanya mencerdaskan para santri tetapi juga mendidik akhlak dan budi pekerti para santri.

Dapat disimpukan bahwa Pondok Pesantren Sidogiri masih eksis dalam mempertahankan nilai-nilai salaf di era globalisasi diantaranya budaya salaf yang masih kental terasa mulai dari pembiasaan sehari-hari pemakaian kitab kuning sebagai sumber utama pembelajaran. Selain itu dalam segala aktifitas santri tak lepas dari memakai sarung. Selain itu, akhlaq para santri dalam kehidupan sehari-hari baik sesama santri, pengurus maupun kepada Ustadz/kyai.

\section{F. Upaya Pondok Pesantren Sidogiri dalam Mempertahankan Nilai-Nilai Salaf di Era Globalisasi}

Upaya yang dilakukan untuk mempertahankan nilai-nilai salaf di Pondok Pesantren Sidogiriyaitu selalu menjaga dan memperbaiki sistem

\footnotetext{
${ }^{35}$ Observasi dilakukan pada tanggal 15 Mei 2016 Pukul 11.00

${ }^{36}$ Observasi dilakukan pada tanggal 8 Mei 2016 Pukul 11.00

${ }^{37}$ Observasi dilakukan pada tanggal 15 Mei 2016 Pukul 10.35
} 
yang ada. Pondok Pesantren Sidogiri mempunyai program study banding yang bertujuan untuk belajar dari tempat-tempat yang lebih bagus sistemnya dan nantinya bisa diterapkan disini.

Selain itu, membuka program Tarbiyah Idadiyah adalah program baca kitab cepat dengan model klasikal dan menggunakan metode buatan sendiri yaitu Al-Miftah lil-ulum sebagai persiapan bagi santrisantri usia dini. Didirikan pada tahun 1433-1434 H oleh majelis keluarga Pondok Pesantren Sidogiri. Tarbiyah Idadiyah menggunakan sistem modul perjilid dengan satu pembimbing untuk maksimal 15 murid. Dengan metode ini para santri usia dini yang telah bisa membaca AlQur'an tapi belum bisa membaca kitab dalam waktu satu tahun diharapkan sudah mampu membaca kitab Fathul Qorib dengan baik. Untuk anak yang masih masih belum bisa membaca dan menulis Arab dimasukkan kelas shifir terlebih dahulu. ${ }^{38}$

Format pembelajarannya anak yang berusia dini (5-15 tahun) meniscayakan adanya metode belajar yang sesuai karakter dan kejiwaan mereka, sehingga metode pengajarannya diformat dengan dunia anak. Maka metode yang dipakai beragam dan diperkaya dengan nyanyian lagu anak, tebak-tebakan, kompetisi demontrasi dan sebagainya. Kitab pelajaran didesain khusus dengan aneka warna yang menarik disertai gambar dan kolom latihan. Kelas tempat mereka belajar juga tidak menetap satu tempat tapi berpindah-pindah.

Pembelajarannya sendiri ini sebagai respons dan perhatian pengurus dalam upaya peningkatan kualitas baca kitab santri, maka fokus kegiatan adalah upaya pembelajaran baca kitab efektif melalui metode, materi dan guru khusus.

Santri yang mengikuti program ini ditempatkan di asrama khusus, Daerah J khusus bagi santri Idadiyah usia 12 tahun ke bawah. Daerah L khusus bagi santri Idadiyahusia 12 tahun ke atas dan daerah M khusus Idadiyah kelas takhassus yang telah diwisuda tahun sebelumnya, serta kelas taqrib yang pada tahun sebelumnya tidak lulus dalam tes wisuda. Program dan kegiatan daerah khusus Idadiyah berbeda dengan asrama lain. Selama 24 jam mereka berada dalam pengawasan kepala kamar dan guru pembina. Dengan cara seperti ini anak didik lebih terkontrol dan perkembangan keilmuan mereka dapat diketahui secara mudah.

Tarbiyah Idadiyah memiliki 2 tingkatan, yakni Idadiyah I dan Idadiyah II. Idadiyah I adalah tingkatan bagi santri baru. Materi Idadiyah

\footnotetext{
${ }^{38}$ Tim Penyusun Jurnal Tamassya, Berakhlak Bermartabat, hlm.80.
} 
I adalah kitab Al-Miftah lil-ulum jilid I sampai IV, Nadzam, Tashrif dan Fathul Qorib.Setiap jilid ditargetkan selesai dalam waktu minimal 25 hari, sehingga semua jilid bisa ditempuh dalam waktu 100 hari atau 3 bulan 10 hari. Sistem evaluasi Idadiyah I dilaksanakan setiap hari tes tulis dan tes lisan yang dilaksanakan dua kali. Tes lisan pertama disebut tes lisan seleksi dan tes lisan kedua disebut tes kenaikan jilid. ${ }^{39}$

Murid yang sudah lulus tes 4 jilid sebelum pertengahan tahun, akan diwisuda terlebih dahulu tanpa harus menunggu hingga akhir tahun ajaran. Setelah diwisuda santri tersebut diharuskan menghafal kitab Fathul Qorib.

Sedangkan Idadiyah II ada dua bagian, kelas takhassus dan taqrib. Target kelas takhassus adalah santri bisa membaca kitab Fathul Qoribmeliputi lafal, makna terjemah dan pemahaman secara sempurna. Sistem evaluasi takhassus dilaksanakan tiap bulan. Sedangkan Idadiyah kelas taqrib adalah santri Idadiyahyang tahun sebelumnya tidak lulus dalam tes wisuda. Materi pelajarannya sama dengan Idadiyah I. setelah 4 jilid selesai mereka diberi tambahan berupa menghafal matan kitab Fathul Qorib. ${ }^{40}$

Dari penjelaskan di atas, dapat penulis simpulkan bahwa upaya Pondok Pesantren Sidogiri dalam mempertahankan eksistensi pondok dan nilai-nilai salaf sudah cukup maksimal mulai dari sistem yang bagus dengan mengadakan study banding dan kharisma kyai yang dijunjung tinggi oleh para pengurus, alumni maupun santri. Selain itu upaya yang dilakukan yaitu membuat metode sendiri yaitu Al-Miftah lil Ulum program baca kitab cepat. Pondok Pesantren Sidogiri juga memberi jadwal khusus dan rutin kegiatan bahtsul masail untuk membahas masalah-masalah tentang agama dan kaderisasi An-Najah yang bertujuan untuk pendalaman akidah Ahlissunnah wal Jama'ah karena di zaman sekarang mulai bermunculan aliran-aliran yang menyimpang.

\section{G. Penutup}

Sistem pendidikan Pondok Pesantren Sidogiri Pasuruan ada 3 tingkat yaitu; Madrasah Ibtidaiyah, Madrasah Tsanawiyah dan Madrasah Aliyah. Sedangkan untuk santri baru wajib mengikuti Madrasah Idadiyah. Untuk mempertahan nilai-nilai salafnya pondok sidogiri masih menggunakan kitab kuning atau kitab klasik dalam proses ta'lim. Dalam metode pengajarannya masih menerapkan metode-

\footnotetext{
${ }^{39}$ Tim Penyusun Jurnal Tamassya, Berakhlak Bermartabat, hlm.81.

${ }^{40}$ Tim Penyusun Jurnal Tamassya, Berakhlak Bermartabat, hlm. 81.
} 
metode salaf seperti sorogan dan wetonan. Selain itu kegiatan-kegiatan religius tetap dipertahankan serta penanaman tawadhu'antara santri dan guru baik dilingkungan pesantren maupun diluar. Adapun upaya pondok sidogiri dalam mempertahankan eksistensi dan nilai-nilai salafnya di era globalisasi saat ini dengan mengadakan studi banding antar pesantren, membuat metode baca kitab cepat yang dinamai dengan Al-Miftah lil Ulum sebagai persiapan bagi santri-santri usia dini, serta memberi jadwal khusus dan rutin kegiatan bahtsul masail untuk membahas persoalan-persoalan agama terkini dan kaderisasi An-Najah yang bertujuan untuk pendalaman akidah Ahlissunnah wal Jama'ah dan ilmu-ilmu kemasyarakatan.

\section{Daftar Pustaka}

Amin Rais, Cakrawala Islam, Antara Cita dan Fakta, (Bandung:

Mizan, 1989).

http://waromuhammad.blogspot.co.id/2012/03/pesantren-dalam-

era-modern.html, diakses pada tanggal 3 September 2016 pukul 23.56

http://waromuhammad.blogspot.co.id/2012/03/pesantren-dalamera-modern.html, diakses pada tanggal 3 September 2016 pukul 23.56

Imam Bawani MA, Tradisionalisme dalam Pendidikan Islam, (Surabaya : al-ikhlas, 1993).

Imron Arifin, Kepemimpinan Kyai, (Malang: Kalimasahada Press, 1993).

Iskandar Engku, Sejarah Pendidikan Islam, (Bandung: Remaja

Rosdakarya, 2014).

Muhammad Sulton Fatoni, Kapital Sosial Pesantren, (Jakarta :Universitas Indonesia, 2015)

Sukamto, Kepemimpinan KIAI Dalam Pesantren, (Jakarta: Pustaka LP3ES, 1999).

Tim Penyusun Jurnal Tamassya, Berakhlak Bermartabat, (Pasuruan: Sekretariat Pondok Pesantren Sidogiri, 2016).

Zamakhsyari Dhofier, Tradisi Pesantren, (Jakarta: LP3ES, 1983). 